See Article page 26.

\section{Commentary: The story of body mass index and transcatheter aortic valve replacement remains incomplete}

\author{
Raymond J. Strobel, MD, MSc, \\ J. Hunter Mehaffey, MD, MSc, and \\ Robert B. Hawkins, MD, MSc
}

In this issue of JTCVS Open, van Nieuwkerk and coauthors ${ }^{1}$ present a multicenter, international, retrospective analysis of the impact of body mass index (BMI) on outcomes following transcatheter aortic valve replacement (TAVR). Ultimately, 12,381 patients undergoing TAVR with either a balloon-expandable or self-expandable device between 2007 and 2018 were included in the authors' analysis. The primary endpoints of the analysis were 30-day and 1year all-cause mortality and stroke. Secondary outcomes included stroke, myocardial infarction, life-threatening or major bleeding, requirement for a permanent pacemaker, and new-onset atrial fibrillation. On multivariable Cox regression, 1-year mortality was significantly higher among underweight patients (hazard ratio, 1.52; 95\% confidence interval, 1.10-2.09) compared with normal-weight patients. Overweight and obese patients did not have a significantly different rate of 1-year mortality or stroke relative to normal-weight patients. Overweight and obese patients had a significantly higher rate of permanent pacemaker implantation, but a significantly lower rate of major or lifethreatening bleeding.

This study, the largest retrospective analysis to date focused on the relationship between BMI and outcomes in

\footnotetext{
From the Division of Thoracic and Cardiovascular Surgery, Department of Surgery, University of Virginia School of Medicine, Charlottesville, Va. Disclosures: The authors reported no conflicts of interest.

The Journal policy requires editors and reviewers to disclose conflicts of interest and to decline handling or reviewing manuscripts for which they may have a conflict of interest. The editors and reviewers of this article have no conflicts of interest.

Received for publication April 28, 2021; revisions received April 28, 2021; accepted for publication April 28, 2021; available ahead of print May 27, 2021.

Address for reprints: Robert B. Hawkins, MD, MSc, Division of Thoracic and Cardiovascular Surgery, Department of Surgery, University of Virginia School of Medicine, PO Box 800679, Charlottesville, VA 22908 (E-mail: rbh6x@ virginia.edu). JTCVS Open 2021;6:39-40

2666-2736

Copyright (C) 2021 The Authors. Published by Elsevier Inc. on behalf of The American Association for Thoracic Surgery. This is an open access article under the CC BY-NCND license (http://creativecommons.org/licenses/by-nc-nd/4.0/).

https://doi.org/10.1016/j.xjon.2021.04.018
}

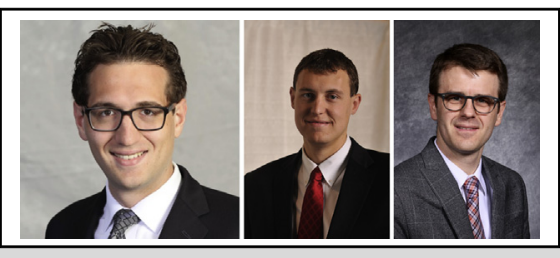

Raymond J. Strobel, MD, MSc, J. Hunter Mehaffey, MD, MSc, and Robert B. Hawkins, MD, MSc

\section{CENTRAL MESSAGE \\ Body mass index $(\mathrm{BMI})>25 \mathrm{~kg} /$ $\mathrm{m}^{2}$ may not be associated with 1- year mortality after TAVR; how- ever, underweight BMI remains an important marker of frailty and risk.}

TAVR, refutes the "obesity paradox" of improved outcomes in overweight and obese patients undergoing TAVR while reaffirming our understanding that low BMI is an important marker of frailty and periprocedural risk. ${ }^{2}$ We know that frailty and sarcopenia add significant risk not currently accounted for in the Society of Thoracic Surgeons risk models for surgical aortic valve replacement (AVR). ${ }^{3}$ Many of these high-risk and frail patients are directed toward TAVR; however, the adjusted odds ratio of 1 -year mortality for underweight patients is 1.5 , a considerable $(50 \%)$ increase. The preprocedure discussion and counseling regarding TAVR needs to emphasize a continued relative risk for underweight and frail patients.

An important limitation of this article is the omission of rates of vascular complications in the study cohort. Obese anatomy often introduces additional difficulty in obtaining vascular access, and the tissues of underweight patients may be more prone to pseudoaneurysm as well. Recently, Sharma and colleagues ${ }^{4,5}$ reported that both underweight (BMI $<18.5 \mathrm{~kg} / \mathrm{m}^{2}$ ) and morbidly obese (BMI $>40 \mathrm{~kg} /$ $\mathrm{m}^{2}$ ) patients had a significantly greater rate of minor vascular complications relative to patients with normal BMI $\left(18.5-24.9 \mathrm{~kg} / \mathrm{m}^{2}\right)$. Despite what the term implies, "minor" vascular complications often require reintervention and include access-site injuries, such as pseudoaneurysm requiring thrombin injection, and failure of percutaneous closure resulting the in need for stenting or cutdown exposure to obtain hemostasis. The lower rate of major bleeding in obese patients undergoing TAVR needs further clarification, as does the higher pacemaker rate, both of which were largely ignored in the authors' discussion but warrant 
consideration in determining valve choice, access site, and closure devices. In some cases, alternative access is required because of body habitus, a decision that will be difficult to account for in retrospective analyses.

As global experience with TAVR as the dominant technique for aortic valve replacement increases, risk counseling for patients suffering from severe, symptomatic aortic stenosis must evolve as well. These findings represent an important contribution to these conversations between patient and physician.

\section{References}

1. van Nieuwkerk AC, Santos RB, Sartori S, Regueiro A, Tchéteché D, Mehran R, et al. For the CENTER collaboration. Impact of body mass index on outcomes in patients undergoing transfemoral transcatheter aortic valve implantation. $J$ Thorac Cardiovasc Surg Open. 2021;6:26-36.

2. Yamamoto M, Mouillet G, Oguri A, Gilard M, Laskar M, Eltchaninoff H, et al. Effect of body mass index on 30- and 365-day complication and survival rates of transcatheter aortic valve implantation (from the French Aortic National CoreValve and Edwards 2 [FRANCE 2] registry). Am J Cardiol. 2013;112: 1932-7.

3. Hawkins RB, Mehaffey JH, Charles EJ, Kern JA, Lim DS, Teman NR, et al. Psoas muscle size predicts risk-adjusted outcomes after surgical aortic valve replacement. Ann Thorac Surg. 2018;106:39-45.

4. Sharma A, Lavie CJ, Elmariah S, Borer JS, Sharma SK, Vemulapalli S, et al. Relationship of body mass index with outcomes after transcatheter aortic valve replacement: results from the National Cardiovascular Data-STS/ACC TVT Registry. Mayo Clin Proc. 2020;95:57-68.

5. Leon MB, Piazza N, Nikolsky E, Blackstone EH, Cutlip DE, Kappetein AP, et al. Standardized endpoint definitions for transcatheter aortic valve implantation clinical trials: a consensus report from the Valve Academic Research Consortium. $J$ Am Coll Cardiol. 2011;57:253-69. 